\title{
FORMULASI DAN UJI SIFAT FISIK SEDIAAN GEL EKSTRAK ETANOLIK GANGGANG HIJAU (ULVA LACTUCA LINN.)
}

\author{
Emelda*, Azizah Nada Septiawan, Dinda Ayu Pratiwi \\ Universitas Alma Ata Yogyakarta \\ *: emelda@almaata.ac.id
}

\begin{abstract}
ABSTRAK
Salah satu penyakit kulit yang seringkali dialami oleh masyarakat adalah jerawat. Bakteri yang banyak terdapat pada pasien yang mengalami jerawat adalah Propionibacterium acnes, Staphylococcus aureus, dan Staphylococcus epidermidis. Sediaan gel dipilih dalam formulasi ini dikarenakan lebih praktis dan awet dalam penyimpanan. Sediaan gel dipilih karena mudah kering, dapat membentuk lapisan film yang mudah dicuci dan memberikan rasa dingin pada kulit. Uji stabilitas fisik perlu dilakukan untuk memastikan kualitas, keamanan dan manfaat gel sehingga memenuhi spesifikasi yang diharapkan dan stabil di dalam penyimpanan. Penelitian ini bertujuan untuk membuat formulasi gel dan mengetahui uji stabilitas sifat fisik sediaan gel ekstrak etanolik ganggang hijau (Ulva lactuca Linn.). Desain penelitian ini adalah eksperimental laboratorium. Formula optimum gel ditentukan berdasarkan variasi konsentrasi Hidroksipropil metilselulosa (HPMC). Gel yang memenuhi kriteria homogenitas, konsistensi, $\mathrm{pH}$ dan daya sebar ditetapkan sebagai formula optimum. Stabilitas fisik formula optimum diuji dengan organoleptik, homogenitas, uji $\mathrm{pH}$, uji daya sebar dan uji viskositas. Gel yang memenuhi kriteria penerimaan adalah gel ektrak etanolik ganggang hijau dengan konsentrasi HPMC 3\% sehingga ditetapkan sebagai formula optimum. Hasil uji stabilitas gel formula optimum tidak menunjukkan adanya perubahan $\mathrm{pH}$, warna, bau dan rasa. Selain itu tidak mengalami perubahan bentuk, viskositas dan daya sebar.
\end{abstract}

Kata Kunci: Ganggang hijau, Ulva lactuca, uji sifat fisik, HPMC

\begin{abstract}
One of the skin diseases that are often experienced by people is acne. The bacteria found in patients with acne are Propionibacterium acnes, Staphylococcus aureus, and Staphylococcus epidermidis. The gel preparation was chosen in this formulation because it is more practical and durable in storage. Gel preparations were chosen because it dry easily, can form a film layer that is easy to wash, and gives a cool feeling to the skin. Physical stability tests need to be carried out to ensure the quality, safety, and usefulness of the gel so that it meets the expected specifications and is stable in storage. This study aims to make a gel formulation and determine the stability test of the physical properties of green algae (Ulva lactuca Linn.) Ethanolic extract gel. The design of this research is laboratory experimental. The optimum gel formula is determined based on variations in the concentration of Hydroxypropyl methylcellulose (HPMC). The Gel that meets the criteria of homogeneity, consistency, $\mathrm{pH}$, and dispersibility is determined as the
\end{abstract}


Emelda

p-ISSN 2621-3184; e-ISSN 2621-4032

doi: $10.36387 /$ jifi.v3i2.654

optimum formula. The physical stability of the optimum formula was tested by organoleptic, homogeneity, $\mathrm{pH}$ test, spreadability test, and viscosity test. The gel that met the acceptance criteria was green algae ethanolic extract gel with a concentration of $3 \%$ HPMC so that it was determined as the optimum formula. The results of the stability test for the optimum gel formula did not show any changes in $\mathrm{pH}$, color, smell, and taste, In addition, there is no change in shape, viscosity, and dispersibility.

Keywords: Green algae, Ulva lactuca, Physical properties test, HPMC

\section{PENDAHULUAN}

Penyakit yang menyerang pada permukaan tubuh terutama pada bagian kulit dapat disebabkan oleh berbagai macam seperti bakteri, virus dan jamur. Salah satu penyakit kulit yang seringkali dialami oleh masyarakat adalah jerawat. Bakteri yang banyak terdapat pada pasien yang mengalami jerawat adalah Propionibacterium acnes, Staphylococcus aureus, dan Staphylococcus epidermidis. 1,2

Antibiotik sistemik dan topikal telah lama menjadi bagian dari terapi untuk mengatasi penyakit kulit ini. Namun kasus resisten terhadap bakteri penyebab jerawat ini terus meningkat setiap tahunnya. Beberapa tanaman obat telah banyak dikembangkan untuk mengatasi kasus tersebut. Hal tersebut juga didukung oleh adanya peningkatan tren back to nature pada masyarakat.
Salah satu tanaman yang dapat mengatasi kasus jerawat adalah ganggang hijau (Ulva lactuca Lin). Telah banyak dilakukan penelitian terkait ganggang hijau sebagai antibakteri.

Efek farmakologis yang dimiliki oleh ganggang hijau (Ulva lactuca) yaitu sebagai antimikroba baik sebagai anti jamur maupun sebagai antimikroba. Pada penelitian yang dilakukan oleh Khaliq et al. (2014) menunjukkan bahwa Ulva lactuca dapat menhambat pertumbuhan beberapa bakteri gram positif maupun negatif seperti Staphylococcus epidermidis , Staphylococcus aureus, Pseudomonas aeruginosa, dan Escherichia coli. Selain itu juga dapat menghambat pertumbuhan jamur seperti Candida albicans dan Aspergilus niger. ${ }^{3}$

Suatu bentuk formulasi sediaan yang dapat mempermudah masyarakat mendapatkan khasiat 
Emelda

p-ISSN 2621-3184 ; e-ISSN 2621-4032

doi: $10.36387 /$ jifi.v3i2.654

antijerawat dari ganggang hijau adalah gel. Gel menjadi sediaan terpilih karena pada formulasinya tidak mengandung minyak, sehingga tidak akan memperburuk jerawat tersebut. ${ }^{4}$ Sifat gel yang tidak lengket, cepat mengering dan stabil dapat memberikan nilai estetika yang baik dan tidak memerlukan energi yang besar untuk formulasi. ${ }^{5}$

Sediaan gel yang baik dapat diperoleh dengan memformulasikan beberapa jenis bahan pembentuk gel dan yang paling penting adalah pemilihan gelling agent. Penambahan gelling agent yang sesuai akan memberikan karakteristik sediaan sesuai dengan spesifikasi dan parameter yang diharapkan. ${ }^{5}$ Selain itu penggunaan jenis dan konsentrasi bahan tambahan maupun ekstrak yang berbeda akan mempengaruhi stabilitas fisik formula gel tersebut.

Tujuan dilakukan penelitian ini adalah membuat suatu formulasi gel antijerawat dari ekstrak etanolik ganggang hijau (Ulva lactuca Linn.) dengan variasi penambahan gelling agent dan melakukan uji sifat fisik dan karakteristik sediaan gel tersebut.

\section{METODE PENELITIAN}

Penelitian ini dilakukan di Laboratorium Teknologi Farmasi, dan Laboratorium Fitokimia Universitas Alma Ata Yogyakarta pada bulan Juli-September 2020 . Desain penelitian adalah eksperimental laboratorium. Kegiatan yang dilakukan adalah determinasi tanaman, pembuatan serbuk dan ekstrak etanolik ganggang hijau, pembuatan sediaan gel, kemudain dilanutkan dengan uji organoleptik, uji homogenitas, uji $\mathrm{pH}$, uji daya sebar, uji daya lekat, uji viskositas dan uji konsistensi.

Peralatan yang digunakan dalam penelitian ini adalah Pisau, nampan, blender (Philips), ayakan mesh, toples kaca, maserator, timbangan analitik (Ohaus), oven, rotary evaporator, waterbath, kain flannel, cawan porselen, alat-alat gelas, mortar, stamper, jangka sorong, $\mathrm{pH}$ meter, viskosimeter Ostwald, kaca bulat berdiameter, object glass (sail-brand), magnetic stirrer.

Bahan yang digunakan dalam penelitian ini adalah ganggang hijau segar (Ulva lactuca Linn.) yang 
Emelda

p-ISSN 2621-3184 ; e-ISSN 2621-4032

doi: $10.36387 /$ jifi.v3i2.654

diperoleh langsung dari pesisir pantai tersebut terendam seluruhnya. Proses di Gunung Kidul Yogyakarta, Bahan kimia yang digunakan adalah etanol $70 \%$, hidroksipropilmetilselulosa (HPMC), propilen glikol, metil paraben, akuadest.

\section{Pengumpulan Tanaman}

Ganggang hijau yang diperoleh dikumpulkan dan dilakukan determinasi tanaman untuk memastikan bahwa bahan yang digunakan sesuai. Determinasi dilakukan di Laboratorium Biologi Universitas Ahmad Dahlan Yogyakarta.

Ganggang hijau segar dicuci dengan air mengalir, kemudian dipotong-potong, dikeringkan dalam oven dan dihaluskan dengan menggunakan blender. Serbuk kasar hasil dari blender, kemudian diayakan dengan menggunakan ayakan no.40 untuk mendapatkan serbuk ganggang hijau yang lebih halus.

\section{Proses Ekstraksi}

Metode yang dipilih untuk proses ekstraksi adalah maserasi. Sebanyak 500 gram serbuk ganggang hijau dimasukkan ke dalam toples kaca kemudian ditambahkan dengan 2 liter pelarut etanol $70 \%$ hingga serbuk perendaman dilakukan selama 24 jam dengan dua kali pengulangan (remaserasi). Kemudian dilakukan penyaringan dengan menggunakan kain flannel untuk memisahkan ampas dan filtrat. Filtrat dikumpulkan dan diuapkan dengan menggunakan rotary evaporator pada suhu $40^{\circ} \mathrm{C}$ dan dilanjutkan dengan menggunakan waterbath hingga diperoleh ekstrak yang kental kemudian dihitung rendemennya. ${ }^{7}$

Rendemen

$$
=\frac{\text { Berat ekstrak kental }}{\text { Berat serbuk simplisia }} \times 100 \%
$$

Pembuatan Sediaan Gel Ekstrak Etanolik Ganggang Hijau (Ulva lactuca Linn.)

Pada penelitian ini dibuat sediaan gel dengan variasi konsentrasi gelling agent. Gelling agent yang digunakan adalah hidroksipropilmetilselulosa (HPMC). Formula gel yang dibuat dapat dilihat pada tabel 1 .

Pembuatan sediaan gel dengan menggunakan metode dingin yaitu sejumlah basis HPMC dilarutkan dalam akuadest dan 
Jurnal Insan Farmasi Indonesia, 3(2) Desember 2020 (271-280)

Emelda

p-ISSN 2621-3184 ; e-ISSN 2621-4032

doi: 10.36387/jifi.v3i2.654

dikembangkan dengan cara

didiamkan selama 24 jam.

Tabel 1. Formulasi Sediaan Gel Ekstrak Etanolik Ganggang Hijau

\begin{tabular}{|c|c|c|c|c|}
\hline \multirow{2}{*}{ Komponen } & \multicolumn{3}{|c|}{ Formula } & \multirow{2}{*}{ ket } \\
\hline & I & II & III & \\
\hline $\begin{array}{c}\text { Ekstrak } \\
\text { etanolik } \\
\text { ganggang } \\
\text { hijau (\%) }\end{array}$ & 10 & 10 & 10 & Zat Aktif \\
\hline HPMC (\%) & 3 & 4 & 5 & $\begin{array}{c}\text { Basis gel } \\
\text { (Gelling } \\
\text { agent) }\end{array}$ \\
\hline $\begin{array}{c}\text { Propilen } \\
\text { glikol } \\
\text { (gram) }\end{array}$ & 15 & 15 & 15 & Humektan \\
\hline $\begin{array}{c}\text { Metil } \\
\text { paraben } \\
(\%)\end{array}$ & 0,2 & 0,2 & 0,2 & Pengawet \\
\hline $\begin{array}{l}\text { Akuadest } \\
\text { (gram) }\end{array}$ & 50 & 50 & 50 & Pembawa \\
\hline
\end{tabular}

Kemudian diaduk homogen

hingga terbentuk massa gel. Selanjutnya Metil paraben dilarutkan dalam sedikit etanol untuk mempermudah kelarutan. Ekstrak etanolik ganggang hijau kemudian ditambahkan, di aduk hingga homogen. Propilen glikol ditambahkan sedikit demi sedikit hingga terbentuk gel yang homogen. Gel yang terbentuk dicukupkan dengan akuadest hingga 50 gram dan terus diaduk sampai terbentuk massa gel yang homogen. ${ }^{5}$

Pengujian Sifat Fisik Sediaan Gel Ekstrak Etanolik Ganggang Hijau

a. Pengujian Organoleptik 
Jurnal Insan Farmasi Indonesia, 3(2) Desember 2020 (271-280)

Emelda

p-ISSN 2621-3184; e-ISSN 2621-4032

doi: $10.36387 /$ jifi.v3i2.654

Uji konsistensi dilakukan dengan mengamati perubahan konsistensi gel apakah terjadi pemisahan atau tidak antara bahan pembentuk gel dengan pembawanya. Pengujian konsistensi dilakukan dengan sentrifugal test yaitu sampel disentrifugasi selama 5 jam pada kecepatan $3800 \mathrm{rpm}$ dan diamati perubahan fisiknya. ${ }^{4}$

\section{HASIL DAN PEMBAHASAN}

Berdasarkan hasil

determinasi tanaman menunjukkan bahwa sampel yang digunakan merupakan ganggang hijau dengan spesies Ulva lactuca Linn dan rendemen yang diperoleh adalah $8 \%$.

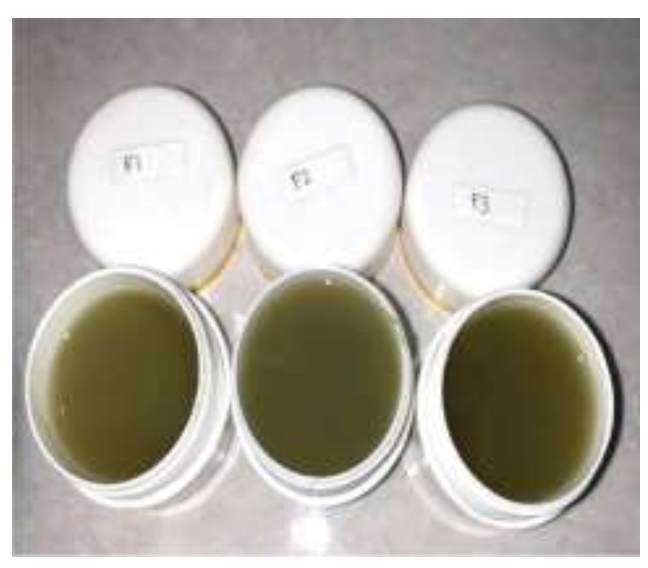

Gambar 1. Hasil Formulasi Sediaan Gel Ekstrak Etanolik Ganggang hijau

Berdasarkan hasil pengamatan organoleptis yang dapat dilihat pada Gambar 1 dan Tabel 2. warna yang dihasilkan sediaan gel formula I, formula II dan formula III adalah hijau tua. Semakin besar konsentrasi HPMC yang digunakan, konsistensi gel tersebut semakin kental.

Tabel 2. Hasil Uji Organoleptis Sediaan Gel Ekstrak Etanolik Ganggang Hijau

\begin{tabular}{cccc}
\hline FORMULA & Bentuk Warna & Bau \\
\hline \multirow{2}{*}{ I } & Kental & $\begin{array}{c}\text { Hijau } \\
\text { tua }\end{array}$ & $\begin{array}{c}\text { Khas } \\
\text { Ganggang } \\
\text { Hijau }\end{array}$ \\
& & & $\begin{array}{c}\text { Khas } \\
\text { II }\end{array}$ \\
& Lebih & Hijau & Ganggang \\
& Kental & tua & Hijau \\
& & & Khas \\
III & Sangat & Hijau & Ganggang \\
& Kental & tua & Hijau \\
\hline
\end{tabular}

Pengamatan homogenitas

(Tabel 3) dilakukan saat sediaan dioleskan pada kaca transparan. Sediaan gel tiap formula menunjukkan warna yang merata dan tidak adanya butiran kasar, sehingga dapat disimpulkan ketiga formula yang dibuat memiliki homogenitas yang baik. Hasil pengamatan menunjukkan tidak adanya pengaruh variasi konsentrasi HPMC terhadap homogenitas gel. 
Emelda

p-ISSN 2621-3184; e-ISSN 2621-4032

doi: $10.36387 /$ jifi.v3i2.654

Tabel 3. Hasil Uji Homogenitas Sediaan Gel Ekstrak Etanolik Ganggang Hijau

\begin{tabular}{cccc}
\hline \multirow{2}{*}{ NO } & \multirow{2}{*}{ FORMULA } & \multicolumn{2}{c}{ Homogenitas } \\
\cline { 3 - 4 } & & Ya & Tidak \\
\hline 1. & F1 & $\sqrt{ }$ & - \\
2. & F2 & $\sqrt{ }$ & - \\
3. & F3 & $\sqrt{ }$ & - \\
\hline
\end{tabular}

Pengukuran $\mathrm{pH}$ bertujuan

untuk mengetahui apakah sediaan yang dihasilkan dapat diterima $\mathrm{pH}$ kulit atau tidak, karena hal ini berkaitan dengan keamanan dan kenyamanan sediaan ketika digunakan. Apabila tidak sesuai dengan $\mathrm{pH}$ kulit maka sediaan dapat menyebabkan iritasi yang mengakibatkan ketidaknyamanan dalam penggunaan. ${ }^{8}$ Rentang $\mathrm{pH}$ sediaan topikal adalah 5-6,5. ${ }^{9}$ Hasil pengamatan uji $\mathrm{pH}$ dapat dilihat pada Tabel 4. bahwa ketiga formulasi memenuhi persyartan karena masih berada pada range $\mathrm{pH}$ normal kulit yaitu 6 .

Tabel 4. Hasil Uji pH sediaan Gel Ekstrak Etanolik Ganggang Hijau

\begin{tabular}{cc}
\hline FORMULA & pH \\
\hline I & 6 \\
II & 6 \\
III & 6 \\
\hline
\end{tabular}

Tabel 5. Hasil Uji Daya Sebar Sediaan Gel Ekstrak Etanolik Ganggang Hijau

\begin{tabular}{|c|c|c|c|}
\hline \multirow{2}{*}{ UJI } & \multicolumn{3}{|c|}{ FORMULA } \\
\hline & I & II & III \\
\hline $\begin{array}{c}\text { Rerata Daya } \\
\text { Sebar (cm) } \\
X \pm S D\end{array}$ & $5,9 \pm 0,06$ & $5,0 \pm 0,16$ & $4,9 \pm 0,05$ \\
\hline $\begin{array}{c}\text { Rerata Daya } \\
\text { Lekat } \\
\text { (Detik) } \\
\mathrm{X} \pm \mathrm{SD}\end{array}$ & $\begin{array}{c}4,89 \pm \\
0,35\end{array}$ & $\begin{array}{c}32,58 \pm \\
1,65\end{array}$ & $\begin{array}{c}47,34 \pm \\
2,54\end{array}$ \\
\hline $\begin{array}{c}\text { Uji } \\
\text { Konsistensi }\end{array}$ & $\begin{array}{c}\text { Kental } \\
\text { lunak } \\
\text { tidak } \\
\text { terjadi } \\
\text { pemisahan }\end{array}$ & $\begin{array}{c}\text { Kental } \\
\text { lunak } \\
\text { tidak } \\
\text { terjadi } \\
\text { pemisahan }\end{array}$ & $\begin{array}{c}\text { Kental } \\
\text { lunak } \\
\text { tidak } \\
\text { terjadi } \\
\text { pemisahan }\end{array}$ \\
\hline
\end{tabular}

Pengujian daya sebar gel bertujuan untuk mengetahui seberapa baik sediaan gel menyebar pada permukaan kulit, karena dapat mempengaruhi absorbsi obat dan kecepatan pelepasan zat aktif di tempat pemakaiannya. Suatu sediaan yang baik dan lebih disukai bila dapat menyebar dengan mudah pada kulit dan nyaman digunakan. ${ }^{10}$ Daya sebar sediaan topikal yang sesuai dengan persyaratan yaitu $5-7 \mathrm{~cm} .^{11}$

Hasil pada Tabel 5. menunjukkan bahwa formula I dengan konsentrasi HPMC yang rendah menghasilkan sediaan yang kurang kental jika dibandingkan pada formula II dan III sehingga memiliki rentang penyebaran yang lebih luas 
Emelda

p-ISSN 2621-3184 ; e-ISSN 2621-4032

doi: 10.36387/jifi.v3i2.654

dibandingkan formulasi II dan III.

Uji sentrifugasi bertujuan Penurunan nilai daya sebar ini disebabkan karena perbedaan konsentrasi HPMC pada masingmasing formula. Semakin tinggi nilai konsentrasi gelling agent yang digunakan maka akan terjadi penurunan nilai daya sebar. Dari hasil tersebut menunjukkan formula III tidak memenuhi persyaratan daya sebar gel yang baik.

Sedangkan hasil uji daya lekat pada Tabel 5. menunjukkan bahwa daya lekat yang paling lama terdapat pada formula III dengan rata-rata 50,21 detik, hal ini dikarenakan semakin tinggi konsentrasi HPMC maka daya lekat suatu formula semakin besar. HPMC mampu membentuk koloid dengan penambahan air panas, dimana koloid terbentuk oleh zat yang terdispersi dan mengabsorbsi medium pendispersinya sehingga menjadi kental dan bersifat lengket, oleh karena itu semakin tinggi kadar HPMC maka koloid yang terbentuk akan semakin banyak dan mampu meningkatkan daya lekat. ${ }^{12}$ Dari ketiga formula tersebut, semua menunjukkan daya lekat yang baik. untuk mengamati apakah terjadi pemisahan fase pada sediaan dan untuk melihat kestabilan sediaan gel saat dilakukan pengocokan yang sangat kuat. Hasil uji yang diperoleh pada Gambar 2. menunjukkan bahwa ketiga formula tidak mengalami pemisahan fase atau sineresis, sehingga dapat disimpulkan ketiga sediaan gel stabil. ${ }^{13}$

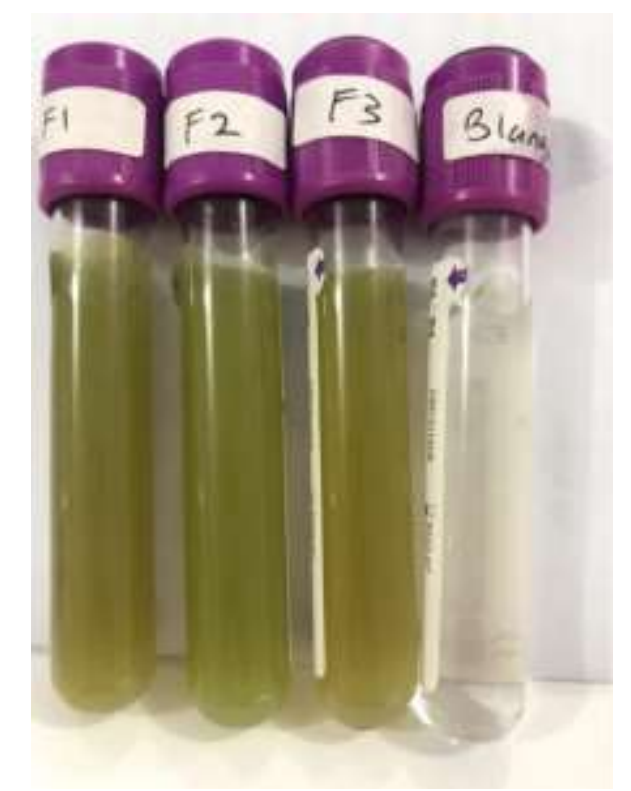

Gambar 2. Hasil Uji Konsistensi Sediaan Gel Ekstrak Etanolik Ganggang Hijau

KESIMPULAN

Formula optimum gel ekstrak etanolik ganggang hijau (Ulva lactuca Linn.) diperoleh pada formula 
Emelda

p-ISSN 2621-3184; e-ISSN 2621-4032

doi: 10.36387/jifi.v3i2.654

yang mengandung Gelling agent

HPMC dengan konsentrasi 3\%.

\section{DAFTAR PUSTAKA}

1. Lee, Byun, \& Kim. (2019). Potential Role of the Microbiome in Acne: A Comprehensive Review. Journal of Clinical Medicine, $\quad 8(7), \quad 987$. https://doi.org/10.3390/jcm8070 $\underline{987}$

2. Nakase, K., Nakaminami, H., Takenaka, Y., Hayashi, N., Kawashima, M., \& Noguchi, N. (2014). Relationship between the severity of acne vulgaris and antimicrobial resistance of bacteria isolated from acne lesions in a hospital in Japan. Journal of Medical Microbiology, 63(PART 5), 721728.

https://doi.org/10.1099/jmm.0.0 67611-0

3. Abdel-Khaliq, A., Hassan, H. M., Rateb, M. E., \& Hammouda, O. (2014). Antimicrobial Activity of Three Ulva Species Collected from Some Egyptian Mediterranean Seashores. International Journal of Engineering Research and General Science, 2(5). www.ijergs.org

4. Arista, Y., Kumesan, N., Yamlean, P. V. Y., \& Supriati, H. S. (2013). Formulasi Dan Uji Aktivitas Gel Antijerawat Ekstrak Umbi Bakung (Crinum Asiaticum L.) Terhadap Bakteri Staphylococcus Aureus Secara in Vitro. PHARMACON Jurnal Ilmiah Farmasi - UNSRAT, 2(02), 2302-2493.

5. Emelda, E. (2020). Formulasi

dan Uji Sifat Fisik Sediaan Gel Tunggal dan Kombinasi Ekstrak Etanolik Daun Sirih Merah (Pipper crocatum) dan Minyak Kayu manis (Cinnamon oil). INPHARNMED Journal (Indonesian Pharmacy and Natural Medicine Journal), 4(2), 43.

https://doi.org/10.21927/inpharn med.v4i2.1405

6. Sayuti, N. A., Jamu, J., \& Kemenkes Surakarta, P. (2015). Formulasi dan Uji Stabilitas Fisik Sediaan Gel Ekstrak Daun Ketepeng Cina (Cassia alata L.) Formulation and Physical Stability of Cassia alata L. Leaf Extract Gel. In Jurnal Kefarmasian Indonesia (Vol. 5, Issue 2). Badan Penelitian dan Pengembangan Kesehatan, Kementerian Kesehatan Republik Indonesia.

7. Emelda, E. (2017). POTENSI TONGKAT ALI (Eurycoma longifolia Jack.) SEBAGAI ANTI INFLAMASI |. JCPS (Journal of Current Pharmaceutical Sciences).

https://journal.umbjm.ac.id/inde x.php/jcps/article/view/78

8. Trenggono R., Latifah F. Buku Pegangan Ilmu Pengetahuan Kosmetik. In Jakarta: PT. Gramedia; 2007.

9. Astuti D. Formulasi Sediaan Gel Ekstrak Etanolik Buah Mahkota Dewa (Phaleria Macrocarpa (Scheff Boerl.) dengan Basis HPMC. 2012.

10. Wyatt EL, Sutter SH, Drake L. (2008) Dermatology Pharmacology. $10^{\text {th }}$ edition. In Hardaman JG, Limbird LE, Gilman AG, editors. New York: 
Jurnal Insan Farmasi Indonesia, 3(2) Desember 2020 (271-280)

Emelda

p-ISSN 2621-3184 ; e-ISSN 2621-4032

doi: 10.36387/jifi.v3i2.654

Gilman's the Pharmacological Basis of Therapeutics.

11. Garg A, Aggarwal D, Garg S, Sigla AK. (2002). Spreading of Semisolid Formulation: an Update. USA: Pharmaceutical Tecnology; 84-102 p.

12. Rowe RC, Sheskey PJ, Quinn ME. 2009. Handbook of
Pharmaceutical Excipients. Sixth Edition. London: Pharmaceutical Press

13. Suryani N, Mubarika ND, Komala I. (2019).Pengembangan dan Evaluasi Stabilitas Formulasi Gel yang Mengandung Etil $p$ metoksisinamat. Pharmaceutical Biomedical Sciences J.;1:29-36. 